\title{
The Lanthanum Hydroxide Fluoride Carbonate System: The Preparation of Synthetic Bastnaesite
}

\author{
JOHN M. HASCHKE \\ Department of Chemistry, University of Michigan, Ann Arbor, Michigan 48104
}

Received December 18, 1973

\begin{abstract}
Hydrothermal phase equilibria in the lanthanum + hydroxide + fluoride + carbonate system have been investigated along an isobaric and isothermal section of variable metal to fluoride ratio, $x$. Quantitative substitution of fluoride into $\mathrm{LaOHCO}_{3}$ proceeds with the formation of a continuous solid solution, $\mathrm{La}(\mathrm{OH})_{1-x} \mathrm{~F}_{x} \mathrm{CO}_{3}$, for $0 \leqslant x \leqslant 1$ and a two-phase region, $\mathrm{LaFCO}_{3}+\mathrm{LaF}_{3}$, for $1<x<3$. Single crystal X-ray diffraction data show that untwinned $\mathrm{LaOHCO}_{3}$ is an orthorhombic phase $\left(a=21.891(5), b=12.639(3)\right.$ and $c=10.047(2) \AA$ ) which is not isostructural with $\mathrm{LaFCO}_{3}$. Hydrolysis of the $\mathrm{La}(\mathrm{OH})_{1-x} \mathrm{~F}_{x} \mathrm{CO}_{3}$ phase to the corresponding $\mathrm{UCl}_{3}$-type $\mathrm{La}(\mathrm{OH})_{3-x} \mathrm{~F}_{x}$ compositions has been observed. Thermal decomposition reactions of the hydroxide fluoride carbonates are described, and a geochemical process for the formation of bastnaesite and tysonite is proposed.
\end{abstract}

\section{Introduction}

The preparation and some properties of the anhydrous hydroxide carbonates, $\mathrm{LnOHCO}_{3}$ $(\mathrm{Ln}=\mathrm{La}, \mathrm{Pr}, \mathrm{Nd}, \mathrm{Sm}, \mathrm{Gd})$, have recently been described in several independent reports $(1-3)$. In each case, the data for these phases, which are obtained by hydrolysis of the sesquicarbonates at high temperature and pressure, have indicated that they are compositional and structural analogs of bastnaesite, $\mathrm{LnFCO}_{3}$. Sawyer, Caro, and co-workers $(2,4)$ have also suggested that the so-called "dense $\mathrm{La}(\mathrm{OH})_{3}$ " phase observed in the hydrothermal $\mathrm{La}_{2} \mathrm{O}_{3}+\mathrm{H}_{2} \mathrm{O}$ system (5) is actually the hydroxide carbonate; however, several of its weak $X$-ray diffraction lines cannot be indexed on a $\mathrm{LnFCO}_{3}$-type cell (4).

An interest in further crystallographic characterization of the $\mathrm{LnOHCO}_{3}$ phase and in examining the possible existence of miscibility between the hydroxide carbonates and fluoride carbonates has prompted an investigation of the crystal chemistry and phase equilibria of the lanthanum + hydroxide + fluoride + carbonate system.

Copyright (C) 1975 by Academic Press, Inc. All rights of reproduction in any form reseryed. Printed in Great Britain

\section{Experimental Section}

Lanthanum hydroxide carbonate was prepared by hydrolysis of the hydrated lanthanum(III) carbonate under hydrothermal conditions. The amorphous carbonate was obtained by dissolution of $\mathrm{La}_{2} \mathrm{O}_{3} \quad(99.9 \%$ purity, American Potash and Chemical Corp., Code 528) in minimal $\mathrm{HCl}$, precipitation with $\left(\mathrm{NH}_{4}\right)_{2} \mathrm{CO}_{3}$ (reagent grade, General Chemical Division, Allied Chemical) and digestion in air. Carbonate samples $(0.5-2.0 \mathrm{~g})$ were enclosed in tightly crimped gold capsules and reacted in cold-seal pressure vessels (3) at $500^{\circ} \mathrm{C}$ and $1000 \mathrm{~atm}$ water pressure.

Equilibria in the $\mathrm{La}+\mathrm{OH}+\mathrm{F}+\mathrm{CO}_{3}$ system were examined along an isobaric (1200 \pm $50 \mathrm{~atm})$ and isothermal $\left(600 \pm 25^{\circ} \mathrm{C}\right)$ section of variable fluoride content. Samples of $\mathrm{LaOH}$ $\mathrm{CO}_{3}(0.2-0.5 \mathrm{~g})$, which were combined with selected molar ratios $(0<x<10)$ of $\mathrm{NH}_{4} \mathrm{~F}$ (reagent grade, J. T. Baker Chemical Co.) and water, were sealed in welded gold capsules and reacted for periods of 3-14 days. Several compositions were also reacted at lower pressures. The maximum allowable quantities 
of added solvent were calculated for each capsule by using specific volume data for water at the reaction conditions (6).

Solid reaction products were characterized by $\mathrm{X}$-ray diffraction and chemical analysis. Powder X-ray diffraction data were obtained with a $114.6 \mathrm{~mm}$ Haegg-type Guinier camera using $\mathrm{CuK \alpha} \alpha_{1}$ radiation and silicon $\left(a_{0}=\right.$ $5.4306 \AA$ ) as an internal standard. Single crystals were characterized by equi-inclination Weissenberg techniques using $\mathrm{Cu} K \bar{\alpha}$ radiation; intensity data were collected with a Syntex $P \bar{l}$ diffractometer using $\mathrm{MoK} \alpha_{1}$ radiation. Chemical analyses of hydroxide carbonate samples were obtained by ignition under high purity oxygen. The oxide residues were employed for the determination of metal contents while hydroxide and carbonate analyses were effected gravimetrically by collection on anhydrous magnesium perchlorate and Ascarite, respectively. Compositions of bastnaesite-like $\mathrm{La}(\mathrm{OH}, \mathrm{F}) \mathrm{CO}_{3}$ products were determined from their $\mathrm{H}_{2} \mathrm{O}$ and $\mathrm{CO}_{2}$ analyses and the assumption that both the $\mathrm{La}: \mathrm{CO}_{3}$ and $\mathrm{La}:(\mathrm{OH}+\mathrm{F})$ ratios are unity. Densities were obtained by measuring the buoyancy in bromoform.

Crystals of the hydroxide carbonate were grown under hydrothermal conditions. Pure $\mathrm{LaOHCO}_{3}$ samples were sealed in gold capsules with various mineralizer solutions, $1 \mathrm{M}\left(\mathrm{NH}_{4}\right)_{2} \mathrm{CO}_{3}, 6 \mathrm{M} \mathrm{HNO}_{3}$ and $4 \mathrm{M}$ $\mathrm{NH}_{4} \mathrm{NO}_{3}$, and digested at $500^{\circ} \mathrm{C}$ and 1200 atm for up to $5 \mathrm{wk}$.

Thermal decomposition reactions of the product phases were investigated with a Perkin-Elmer TGS-1 thermobalance. Samples (5-15 mg) were pyrolyzed in Pt boats under dry nitrogen at temperatures up to $825^{\circ} \mathrm{C}$; heating rates were linear at $2.5 \mathrm{deg} / \mathrm{min}$.

\section{Results and Discussion}

\section{$\mathrm{LaOHCO}_{3}$}

The products obtained by hydrolysis of the sesquicarbonate are finely divided polycrystalline materials with the composition $\mathrm{La}(\mathrm{OH})_{1.00 \pm 0.02}\left(\mathrm{CO}_{3}\right)_{1.00 \pm 0.02}$. The powder $\mathrm{X}$-ray diffraction data for the hydroxide carbonate (cf. Table I) are consistent with those reported previously for the praseodymium analog (2) and the dense trihydroxide of lanthanum (5). The strong reflections are indexable on the basis of a hexagonal cell $(a=4.213, c=5.023 \AA)$ similar to that suggested for $\mathrm{PrOHCO}_{3}(3)$; however, none of the relatively weak reflections can be assigned to this subcell and only part of them can be indexed with a bastnaesite-type, i.e., $\mathrm{LnFCO}_{3}$ type, cell for which $a=\sqrt{ } 3 A$ subcell and $c=2 C$ subcell. Although the unassignable weak reflections are consistently observed, the possibility of contamination by a second phase cannot be excluded on the basis of these data alone.

After a digestion period of $5 \mathrm{wk}, \mathrm{LaOHCO}_{3}$ crystals were obtained from $4 \mathrm{M} \mathrm{NH}_{4} \mathrm{NO}_{3}$ solution. The needle-shaped crystals varied in size from $0.02 \times 0.02 \times 0.1 \mathrm{~mm}$ to $2 \times$ $2 \times 4 \mathrm{~mm}$. During digestion periods of $1 \mathrm{wk}$, some coarsening of the substrate was observed with $\mathrm{HNO}_{3}$, but mineralizer activity was not evident for $\left(\mathrm{NH}_{4}\right)_{2} \mathrm{CO}_{3}$. The powder X-ray diffraction pattern of crushed crystals is essentially identical to that of the polycrystalline products; however, these data, which are presented in Table I, include additional weak reflections. Weissenberg data collected for several needle-shaped crystals and an intensity data set obtained with the four-circle diffractometer suggest a hexagonal symmetry $(a=12.634(2), \quad c=10.048(2) \AA$, $c$ colinear with the needle axis) with no systematic absences. This hexagonal cell is related to the hexagonal subcell by $a=3 A$ subcell and $c=2 C$ subcell. Although all reflections in the powder data can be indexed with this cell, attempts to solve the Patterson map for possible hexagonal space groups or to correlate the bastnaesite-type metal sublattice with atomic positions in these space groups have been unsuccessful. These results, the absence of systematic extinctions and the failure to observe precise agreement in the intensities of symmetry equivalent reflections suggest that the needle-shaped crystals might be twinned.

One of the larger crystals has been cleaved, and a fragment with sharp optical extinctions has been examined by Weissenberg techniques. Thedataindicate a side-centered orthorhombic lattice, $a=21.891(5), b=12.639(3)$ and $c=$ 
TABLE I

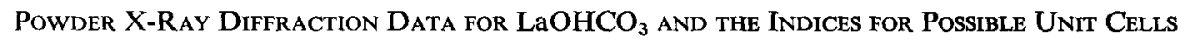

\begin{tabular}{|c|c|c|c|c|c|}
\hline Intensity ${ }^{a}$ & $\begin{array}{c}d_{\text {obsd }} \\
(\AA)\end{array}$ & $\begin{array}{l}d_{\text {calcd }} \\
(\stackrel{\AA}{A})\end{array}$ & $\begin{array}{l}\text { Indices for } \\
\text { orthorhombic cell }\end{array}$ & $\begin{array}{c}\text { Indices for } \\
\text { hexagonal subcell }{ }^{c}\end{array}$ & $\begin{array}{c}\text { Indices for } \\
\text { bastnaesite cell }{ }^{d}\end{array}$ \\
\hline M-S & 5.021 & 5.023 & 002 & 001 & 002 \\
\hline W & 4.133 & 4.137 & $420 ; 510 ; 130$ & - & - \\
\hline $\mathbf{s}$ & 3.648 & 3.648 & $330 ; 600$ & 100 & 110 \\
\hline vW & 3.034 & 3.036 & $240 ; 530 ; 710$ & - & - \\
\hline vS & 2.954 & 2.952 & $332 ; 602$ & 101 & 112 \\
\hline VW & 2.857 & 2.857 & $223 ; 403$ & - & - \\
\hline$w$ & 2.673 & 2.674 & $042 ; 622$ & - & 202 \\
\hline w & 2.601 & $\left\{\begin{array}{l}2.603 \\
2.598\end{array}\right.$ & $\left\{\begin{array}{l}513 ; 133 ; 423 \\
242 ; 532 ; 712\end{array}\right.$ & \{ & \{ \\
\hline $\mathbf{M}$ & 2.510 & 2.511 & 004 & 002 & 004 \\
\hline W & 2.323 & 2.324 & $351 ; 461 ; 911$ & - & 211 \\
\hline VW & 2.296 & 2.298 & $043 ; 623$ & - & 203 \\
\hline w & 2.248 & 2.249 & $243 ; 713$ & - & - \\
\hline W & 2.158 & 2.157 & $352 ; 642 ; 912$ & - & 212 \\
\hline $\mathbf{M}$ & 2,106 & 2.106 & $060 ; 930$ & 110 & 300 \\
\hline $\mathbf{S}$ & 2.069 & 2.069 & $334 ; 604$ & 102 & 114 \\
\hline VW & 2.008 & 2.007 & $552 ; 10,02$ & - & - \\
\hline W & 1.977 & 1.976 & $205 ; 115$ & - & - \\
\hline W & 1.965 & 1.966 & $460 ; 750 ; 11,10$ & - & 204 \\
\hline $\mathbf{M}-\mathbf{S}$ & 1.943 & 1.943 & $062 ; 932$ & 111 & 213 \\
\hline w & 1.888 & 1.886 & $405 ; 225$ & - & 一 \\
\hline M & 1.824 & 1.824 & $660 ; 12,00$ & 200 & 220 \\
\hline W & 1.808 & 1.807 & $135 ; 515$ & - & - \\
\hline $\mathbf{M}$ & 1.715 & 1.714 & $662 ; 12,02$ & 201 & 222 \\
\hline W & 1.675 & 1.674 & 006 & - & 006 \\
\hline vw & 1.654 & 1.655 & $372 ; 953 ; 12,22$ & - & 312 \\
\hline$M$ & 1.614 & 1.614 & $064 ; 934$ & 112 & 304 \\
\hline VW & 1.569 & 1.569 & $155 ; 735 ; 825$ & - & - \\
\hline
\end{tabular}

${ }^{a} \mathrm{~S}=$ strong, $\mathbf{M}=$ medium, $\mathrm{W}=$ weak, $\mathrm{V}=$ very.

${ }^{b}$ Parameters of orthorhombic cell: $a=21.891, b=12.639, c=10.047 \AA$.

c Parameters of hexagonal subcell: $a=4.213, c=5.023 \AA$.

d Parameters of bastnaesite-type cell: $a=7.184, c=9.816 \AA$.

$10.047(2) \AA$, which permits assignment of all the observed reflections in Table I. Intensities in the Weissenberg layers $h k n \quad(n=0-4)$ clearly show that $c$ is only a twofold axis. The hexagonal reciprocal lattice observed for the needle crystals is consistent with a twinning mechanism in which three approximately equal orthorhombic fragments with colinear $c$ axes are intergrown at $60^{\circ}$ angles. For a given $h k n$ layer, the superposition of three orthorhombic reciprocal lattice nets which have been rotated at $60^{\circ}$ to each other generates the apparent sixfold symmetry observed for the uncleaved crystals. Slight differences in the relative sizes of the three fragments would produce the observed intensity variations. Ideally this mechanism requires that $a / b=\sqrt{3}$, a value which agrees exactly with the experimental ratio of 1.7320 . The observed conditions for reflection, $(h k l, h+k=2 n)$ are consistent with space groups $C 222, \mathrm{Cmm} 2$, $\mathrm{Cmmm}$, and $\mathrm{C} 2 \mathrm{~mm}$. Although the Weissenberg data indicate an additional reflection condition $(00 l, l=2 n)$ and the unique space group $C 222_{1}$, the observation of weak odd- $l$ reflections in the diffractometer data for the 
twinned crystals suggests that these reflections are not extinct. The orthorhombic cell is related to the hexagonal subcell by $a=3 \sqrt{3} A$ subcell, $b=3 A$ subcell, $c=2 C$ subcell and $V=36 \mathrm{~V}$ subcell. The measured density of $\mathrm{LaOHCO}_{3}, 4.7(1) \mathrm{g} / \mathrm{cm}^{3}$, indicates that $Z=$ 36 with an X-ray density of $4.64 \mathrm{~g} / \mathrm{cm}^{3}$.

The powder diffraction data in Table $I$ clearly demonstrate that the hydroxide carbonate is not isostructural with bastnaesite, $\mathrm{LnFCO}_{3}$ (4). Although the metal sublattices of $\mathrm{LaOHCO}_{3}$ and bastnaesite appear to be identical, the dissimilar superstructure reflections indicate that small differences exist in the anionic positions of the two materials. Consideration of the bastnaesite structure (7), which is most conveniently described as a layered system with alternating sheets of $(\mathrm{LaF})^{2+}$ and $\mathrm{CO}_{3}^{2-}$, suggests a plausible explanation, the slight distortion of carbonate and hydroxide from the bastnaesite positions. A possible origin of such distortion is hydrogen bond formation similar to that observed between chloride and hydroxide in the layered $Y(\mathrm{OH})_{2} \mathrm{Cl}$ structures $(8)$.

The $\mathrm{La}+\mathrm{OH}+\mathrm{F}+\mathrm{CO}_{3}$ System

Quantitative anionic substitution of fluoride in $\mathrm{LaOHCO}_{3}$ has been observed for $\mathrm{LaOHCO}_{3}: \mathrm{F}$ ratios in the range $0<x<3$. For $x \leqslant 1$, hydroxide replacement by fluoride results in the formation of a continuous solid solution, $\mathrm{La}(\mathrm{OH})_{1-x} \mathrm{~F}_{x} \mathrm{CO}_{3}$, across the entire composition range. For $1<x<3$, carbonate is replaced by fluoride and a mixture of $\mathrm{LaFCO}_{3}$ and $\mathrm{LaF}_{3}$ is observed. At values of $x \geqslant 3$, anionic substitution is complete, and the only product is $\mathrm{LaF}_{3}$. Crystallographic data for various fluoride substitution phases are presented in Table II.

The substitution of fluoride into $\mathrm{LaOHCO}_{3}$ proceeds rapidly with the formation of basic $\mathrm{NH}_{4} \mathrm{OH}$ solutions; analytical results show that the reaction is quantitative. The preparation of an analogous $\mathrm{Ln}(\mathrm{OH}, \mathrm{Cl}) \mathrm{CO}_{3}$ phase by a similar procedure has been reported $(l)$, but extensive data on the crystallographic properties and composition limits of the phases are not available. The polycrystalline fluoride products generally exhibit sharp diffraction patterns with strong subcell re-
TABLE II

Latrice Pakameters hok Vakious Hexagonal Lanthanide Hydroxide Fluoride Carbonate COMPOUNDS $^{a, b}$

\begin{tabular}{lcc}
\hline & \multicolumn{2}{c}{ Lattice parameter } \\
\cline { 2 - 3 } Compound & $a(\AA)$ & $c(\AA)$ \\
\hline $\mathrm{LaOHCO}_{3}$ & $4.213(1)$ & $5.023(1)$ \\
$\mathrm{La}(\mathrm{OH})_{0.75} \mathrm{~F}_{\mathrm{O.25}} \mathrm{CO}_{3}$ & $4.201(1)$ & $4.987(1)$ \\
$\mathrm{La}(\mathrm{OH})_{0.50} \mathrm{~F}_{0.50} \mathrm{CO}_{3}$ & $4.179(2)$ & $4.945(4)$ \\
$\mathrm{La}(\mathrm{OH})_{0.25} \mathrm{~F}_{0.75} \mathrm{CO}_{3}$ & $4.168(1)$ & $4.933(2)$ \\
$\mathrm{LaFCO}$ & $4.148(1)$ & $4.908(1)$ \\
$\mathrm{La}(\mathrm{OH})_{2.75} \mathrm{~F}_{0.25}$ & $6.491(3)$ & $3.858(1)$ \\
$\mathrm{La}(\mathrm{OH})_{2.50} \mathrm{~F}_{0.50}$ & $6.448(4)$ & $3.857(2)$ \\
$\mathrm{La}(\mathrm{OH})_{2.25} \mathrm{~F}_{0.75}$ & $6.428(4)$ & $3.858(1)$ \\
$\mathrm{LaF}$ & $7.190(3)$ & $7.356(2)$ \\
\hline
\end{tabular}

a Parameters for the $\mathrm{La}(\mathrm{OH})_{1-x} \mathrm{~F}_{x} \mathrm{CO}_{3}$ phase are refined for the hexagonal subcell.

${ }^{b}$ Uncertainty in the last digit appears in parentheses.

flections characteristic of the $\mathrm{LaOHCO}_{3}$ and $\mathrm{LaFCO}_{3}$ compositions. Lattice parameters for the hexagonal subcells of $\mathrm{La}(\mathrm{OH})_{1-x} \mathrm{~F}_{x} \mathrm{CO}_{3}$ products are presented in Table II and Fig. 1. The system obviously obeys Vegard's law; however, differences in the superstructure reflections are observed across the composition range. At the $\mathrm{La}(\mathrm{OH})_{0.75} \mathrm{~F}_{0.25} \mathrm{CO}_{3}$ composition, an orthorhombic $\mathrm{LaOHCO}_{3}$-type superlattice is observed; at the $\mathrm{La}(\mathrm{OH})_{0.25}$ $\mathrm{F}_{0.75} \mathrm{CO}_{3}$ composition, only superstructure lines characteristic of bastnaesite are detectable. In the middle of the miscibility range a high level of disorder is indicated by the absence of sharp superstructure reflections, by broadened diffraction lines, and by comparatively high uncertainties in the lattice parameters. The presence of identical sublattices in the hydroxide carbonate and fluoride carbonate and the gradual structural transition from a $\mathrm{LaOHCO}_{3}$-type to a $\mathrm{LaFCO}_{3}$-type lattice suggests that microdomains of the two phases are coherently intergrown in the $\mathrm{La}(\mathrm{OH})_{1-x} \mathrm{~F}_{x} \mathrm{CO}_{3}$ phase.

Difficulties were encountered with reactions in the $x \leqslant 1$ range. Ideally the bastnaesite composition, $\mathrm{LaFCO}_{3}$, should be obtained at $x=1$; however, all products contain mix- 


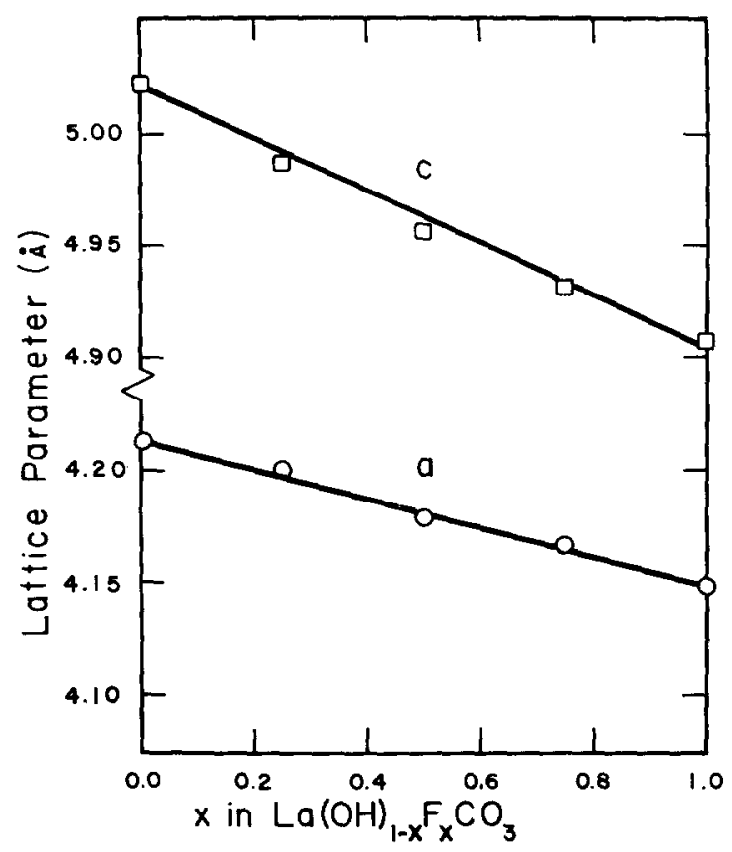

FIG. 1. Dependence of the hexagonal subcell parameters on composition of the $\mathrm{La}(\mathrm{OH})_{1-x} \mathrm{~F}_{x} \mathrm{CO}_{3}$ phase.

tures of $\mathrm{LaF}_{3}$ and a corresponding La$(\mathrm{OH})_{1-x} \mathrm{~F}_{x} \mathrm{CO}_{3}$ phase with $x<1$. Since the quantity of water which could be added to the capsules was insufficient for dissolution of the $\mathrm{NH}_{4} \mathrm{~F}$, formation of the trifluoride appears to be a kinetically controlled process resulting from inhomogeneity in fluoride concentration of the reaction mixture. Fluoride and carbonate mobilities are apparently so low that equilibrium is not established during the time interval of the reaction. The lattice parameters reported for pure $\mathrm{LaFCO}_{3}$ are the constant values observed in the twophase region $1<x<3$. Within the limits of uncertainty in $x, \pm 2 \mathrm{~mole} \%$, chemical analysis showed that these mixtures are free of hydroxide. The reported values also agree with those obtained by extrapolation in Fig. 1 .

Another difficulty is that small quantities of hexagonal $\mathrm{UCl}_{3}$-type compounds were generally found to coexist with $\mathrm{La}(\mathrm{OH})_{1-x} \mathrm{~F}_{x} \mathrm{CO}_{3}$ phases. The lattice parameters for the second phases show a regular variation with the reactant ratio $x$, and their mole fraction is increased by hydrothermal annealing; however, at each composition the lattice para5 meters for both the $\mathrm{La}(\mathrm{OH})_{1-x} \mathrm{~F}_{x} \mathrm{CO}_{3}$ and the UCl-type phases are constant with reaction time. These observations and the crystallographic data for these hexagonal materials suggest that they are lanthanum hydroxide fluorides, $\mathrm{La}(\mathrm{OH})_{3-x} \mathrm{~F}_{x}$, similar to those observed across the lanthanide series (9). Pure samples were not obtained for analysis, but the compositions of these phases have been estimated from their crystallographic data and the assumption that the lanthanum system has approximately the same Vegard's law dependence as other lanthanide hydroxide fluorides (9). Within the limits of uncertainty, \pm 0.05 in $x$, the La: $\mathrm{F}$ ratio, $x$, in the $\mathrm{LnOH}_{3-x} \mathrm{~F}_{x}$ phases, is identical to that in the coexisting $\mathrm{La}(\mathrm{OH})_{1-x} \mathrm{~F}_{x} \mathrm{CO}_{3}$ compounds. Lattice parameters for representative hydroxide fluoride compositions are presented in Table II. At $600^{\circ} \mathrm{C}$ and $1200 \mathrm{~atm}$, hydrolysis of pure $\mathrm{LaOHCO}_{3}$ is not observed, but the $\mathrm{La}(\mathrm{OH})_{1-x} \mathrm{~F}_{x} \mathrm{CO}_{3}$ phase apparently reacts with high pressure water to form the corresponding $\mathrm{La}(\mathrm{OH})_{3-x} \mathrm{~F}_{x}$ compositions and an equilibrium concentration of bicarbonate. Studies of the pressure dependence of the 
system show that at $600^{\circ} \mathrm{C}$ and below 800 atm the $\mathrm{La}(\mathrm{OH})_{1-x} \mathrm{~F}_{x} \mathrm{CO}_{3}$ phase is stable with respect to hydrolysis. The $\mathrm{La}(\mathrm{OH})_{3-x} \mathrm{~F}_{x}$ compositions obtained by the hydrolysis reaction are outside the limits of the single-phase region $(0.95<x<1.15)$ observed at $450^{\circ} \mathrm{C}$ and $4000 \mathrm{~atm}(9)$ and suggest that the miscibility gap between $\mathrm{La}(\mathrm{OH})_{3}$ and $\mathrm{La}(\mathrm{OH})_{2} \mathrm{~F}$ closes rapidly at higher temperatures.

For $x>1$, the hydroxide and then the carbonate are quantitatively replaced by fluoride. This process yields a mixture of $\mathrm{LaFCO}_{3}$ and $\mathrm{LaF}_{3}$ for $1<x<3$ and the pure trifluoride for $x \geqslant 3$. The products have sharp invariant diffraction patterns, and the lattice parameters for $\mathrm{LaF}_{3}$ (cf. Table II) are in excellent agreement with those for the trifluoride prepared under anhydrous conditions (10).

\section{Thermal Decomposition}

The thermal decomposition reactions of $\mathrm{LaOHCO}_{3}$ and $\mathrm{LaFCO}_{3}$ have been determined from tga data. Between 425 and $525^{\circ} \mathrm{C}$, the hydroxide carbonate loses $\mathrm{H}_{2} \mathrm{O}$ and $\mathrm{CO}_{2}$ to form $\mathrm{La}_{2} \mathrm{O}_{2} \mathrm{CO}_{3}$, which subsequently decomposes to $\mathrm{La}_{2} \mathrm{O}_{3}$ between 625 and $800^{\circ} \mathrm{C}$. These results are consistent with the formation of type I dioxide monocarbonate, which decomposes at a lower temperature than the type II phase $(11,12)$. The second plateau reported by Aumont et al. (I) for the decomposition of $\mathrm{LaOHCO}_{3}$ apparently results from the presence of a small fraction of the type II product. Pyrolysis of $\mathrm{LaFCO}_{3}$ occurs between 520 and $550^{\circ} \mathrm{C}$ with the formation of LaOF. The $\mathrm{La}(\mathrm{OH})_{1-x} \mathrm{~F}_{x} \mathrm{CO}_{3}$ phase is like its chloride analog, which pyrolyzes to a mixture of the dioxide monocarbonate and the oxide halide (l).

\section{Conclusions}

The chemical processes employed in this investigation provide a plausible reaction path for the geochemical occurrence of the cerium group elements in bastnaesite and tysonite minerals. In the presence of atmospheric carbon dioxide, the oxides and hydroxides of these elements readily form carbonates; under hydrothermal conditions and in the presence of soluble fluorides, the reaction products hydroxide carbonate, hydroxide fluoride carbonate, bastnaesite and ultimately tysonite are expected in sequence. The quantity of available fluoride determines which mineral is formed. This mechanism accounts for the natural occurrence of the so-called "hydroxylbastnaesites," which have high hydroxide contents and larger lattice parameters than the "fluorobastnaesites" $(13,14)$ and for the frequent coexistence of $(\mathrm{Ce}) \mathrm{FCO}_{3}$ and $(\mathrm{Ce}) \mathrm{F}_{3}$. The model assumes that the lanthanide elements are segregated as the oxides or the hydroxides before reaction with carbon dioxide and fluoride, and its critical evaluation from a geological perspective is necessary.

The hydrothermal reactions appear to provide a uniquely successful method for preparing synthetic bastnaesite. Fridman and co-workers $(15,16)$ have obtained amorphous, hydrated fluoride carbonates by precipitation techniques, but the only reported preparation of the anhydrous material is that of Jansen et al. (17), who obtained it from aqueous solution at ambient pressures. However, the crystallographic data for their product suggest that it is not pure fluoride carbonate. Lattice parameters for this synthetic phase (true cell: $a=7.24, c=9.92 \AA$; subcell : $a=4.18$, $c=4.96 \AA$ ) are appreciably larger than those of natural bastnaesites $(4,7,17)$ and those of synthetic $\mathrm{LaFCO}_{3}$ (true cell: $a=7.184, c=$ $9.816 \AA$; subcell: $a=4.148, c=4.908 \AA$ ). Reference to Fig. 1 indicates that the cerium compound is a hydroxide fluoride carbonate with a composition near $\mathrm{Ce}(\mathrm{OH})_{0.5} \mathrm{~F}_{0.5} \mathrm{CO}_{3}$.

The growth of $\mathrm{LaOHCO}_{3}$ crystals has allowed a partial characterization of its crystal chemistry. A complete structure determination for the hydroxide carbonate will hopefully permit further elucidation of the differences between the hydroxide carbonate and the fluoride carbonate.

\section{Acknowledgment}

The support of a Cottrell Grant from the Research Corporation is gratefully acknowledged. The assistance of Mr. James J. Bartell in the collection of tga data and of Mr. Edward T. Lance in hydrothermal synthesis is appreciated. 


\section{References}

1. R. Aumont, F. Genet, M. Passaret, and Y. Toudic, C.R. Acad. Sci. Paris Ser. C 272, 314 (1971).

2. P. Caro, M. Lemaitre-Blaise, H. Dexpert, and J. SawYer, C.R. Acad. Sci. Paris Ser. C, 27257 (1971).

3. J. M. Haschke and L. Eyring, Inorg. Chem. 10, 2267 (1971).

4. J. Sawyer, P. Caro, and L. Eyring, Rev. Chim. Mineral. 10, 93 (1973).

5. W. M. Shafer and R. Roy, J. Amer. Ceram. Soc. 42, 563 (1959).

6. C. W. Burnham, J. R. Holloway, aND W. F. Davis, Amer. J. Sci. 267-A, 70 (1969).

7. G. Donnay and J, D. H. Donnay, Amer. Mineral. 38, 932 (1953).

8. K. Dornberger-Schiff and R. F. Klevtsova, Acta Cryst. 22, 435 (1967).

9. A. Marbeuf, G. Demazeau, S. Turrell, P.
Hagenmuller, J. Derouet, and P. Caro, J. Solid State Chem. 3, 637 (1971).

10. E. Staritzky and L. B. Asprey, Anal. Chem. 29, 856 (1957).

11. R. P. Turcotte, J. O. Sawyer and L. Eyring, Inorg. Chem. 8, 238 (1969).

12. R. P. Turcotte, J. M. Haschke, M. S. Jenkins, AND L. Eyring, J. Solid State Chem. 2, 593 (1970).

13. I. V. Aleksandrov, V. I. IVANov, AND L. A. Sinkova, Zap. Vses. Mineralog. Obshchestva 94, 323 (1965); Chem. Abstr. 63, 8031h.

14. M. V. Akhmanova and L.P. Orlova, Geokhimiya 1966, 581 (1966); Geochem. Int. 3, 444 (1966).

15. Y. D. Fridman and N. V. Dolgashova, $Z h$. Neorg. Khim. 9, 623 (1964); Russ. J. Inorg. Chem. 9, 345 (1964).

16. Y. D. Fridman and GoroKhov, Zh. Neorg. Khim. 12, 1796 (1967); Russ. J. Inorg. Chem. 12, 945 (1967).

17. G. J. JANSEN, G. B. Magin, Jr., and B. Levin, Amer. Mineral. 44, 180 (1959). 